\title{
Predictors of Academic Self Efficacy: Intolerance of Uncertainty, Positive Beliefs about Worry and Academic Locus of Control
}

\author{
Kıvanç Uzun ${ }^{1} \&$ Zeynep Karataş² \\ ${ }^{1}$ Alumni Relations and Career Planning Coordinator, Burdur Mehmet Akif Ersoy University, Burdur, Turkey \\ ${ }^{2}$ Faculty of Education, Burdur Mehmet Akif Ersoy University, Burdur, Turkey \\ Correspondence: Kıvanç Uzun, Alumni Relations and Career Planning Coordinator, Burdur Mehmet Akif Ersoy \\ University, Burdur, Turkey. E-mail: kuzun@mehmetakif.edu.tr
}

Received: January 12, 2020

Accepted: February 23, 2020

Online Published: May 27, 2020

doi:10.5539/ies.v13n6p104

URL: https://doi.org/10.5539/ies.v13n6p104

\begin{abstract}
Investigation of academic self-efficacy along with intolerance of uncertainty, positive beliefs about worry and academic locus of control is believed to make contributions to the understanding of its complex structure. This study is believed to be of great importance in terms of determining the building blocks to be considered by further research aiming to explain the academic self-efficacy of university students and strengthen their academic self-efficacy. The current study aimed to determine the extent to which the above-mentioned variables predict the academic self-efficacy of university students. The relational survey model was used to reveal the extent to which the above-mentioned variables predict academic self-efficacy. The study was conducted on a total of 717 university students (499 females and 218 males) attending Burdur Mehmet Akif Ersoy University. The data of the current study were collected by using a personal information form developed by the researcher, the academic self-efficacy scale, the intolerance of uncertainty scale, the positive beliefs about worry scale and the academic locus of control scale. In the analysis of the data, Pearson product-moment correlation coefficient and hierarchical multiple regression analysis were used and for this purpose, SPSS 15.0 program was utilized. At the end of the study, it was found that the university students' academic self-efficacy is positively predicted by positive beliefs about worry and academic internal locus of control and negatively predicted by intolerance of uncertainty and academic external locus of control. The findings of the study were discussed in the light of the related studies previously done by the other researchers.
\end{abstract}

Keywords: academic self-efficacy, intolerance of uncertainty, positive beliefs about worry, academic locus of control, university student

\section{Introduction}

Among the common characteristics of the students without any goal, target and plan encountered in schools is there a lack of belief in their potential to achieve any task. This belief is of great importance for students' academic achievement, motivation and directing themselves towards a goal. The individual's thinking that "I can do this task, I can be successful in this course" is an indication of academic self-efficacy, which is also closely associated with self-confidence.

Academic self-efficacy is a strong variable that influences students' lives in social and psychological respects (Wuebbels, 2006), as well as an important determinant of students' academic task and school adjustment performances and academic achievement (Zychowski, 2007). Academic self-efficacy beliefs that make it easier for students to become more interested in and engage with school and school-related tasks can make it possible for them to fulfill their school requirements more effectively (Satici, 2013). It is a fact that individuals with high academic self-efficacy will be more cautious in their academic work or in fulfilling their responsibilities. Individuals seeing themselves academically competent can be different from others with their motivation and devotion.

It is possible to think of academic self-efficacy as a derivation of the concept of self-competence. Self-efficacy is one of the important concepts that were first emphasized in Bandura's social cognitive theory. Bandura (1997) defines self-efficacy as the individual's personal judgment about his/her own ability to demonstrate a performance in any field. When the relevant literature is reviewed, it is seen that there are self-efficacy dimensions related to 
many different behaviors. In other words, the self-efficacy belief makes important contributions to the success in different areas and different situations of life (Bandura, 1997). One of these dimensions is the academic self-efficacy that will contribute to the success of the individual in the academic field.

Academic self-efficacy is defined as the individual's belief that he/she can cope with a subject encountered in an academic field (Bandura, 1997). Individuals with a high level of academic self-efficacy are more enthusiastic and interested in learning experiences than those with low levels of self-efficacy, are able to demonstrate more effective strategies to cope with the difficulties encountered and invest more efforts in their learning lives (Eggen \& Kauchak, 1999). All these show that the academic achievement of students is not independent from their academic self-efficacy beliefs.

Most of the people have uncertainties about their present or future lives. Education system in Turkey is subject to frequent changes. In the next academic year, students are fearful of how they will face a change. Central examination systems and placement procedures in our country are constantly changing. As a result of intensive studies, students can gain an undergraduate program at the university. However, the balance of supply and demand in business life is constantly changing. For these reasons, post-graduation employment for students is uncertain. All these uncertainties occupy the minds of the students. It is also discouraging for students preparing for a career. It can be predicted that this situation will have a negative effect on the motivation and self-efficacy of the students for their academic studies (Fetherston, Cherney, \& Bunton, 2018). Thus, it can be thought that the concept of uncertainty is closely associated with the academic self-efficacy of individuals. Uncertainty is expressed as the inability to precisely predict what is to be encountered as a result of an event or any behavior (Sari, 2007). Behavior exhibited in case of an event considered to be dangerous by the individual can be demonstrated in two ways as either obedience or rejection. If these two behaviors are demonstrated when an uncertain event that is inconsistent and difficult to understand is experienced for the first time, then, it can be said that the person cannot tolerate uncertainty (Stanley-Budner, 1962). Intolerance of uncertainty is expressed as the tendency to react negatively in emotional, behavioral and mental areas in the face of uncertain events and situations (Dugas, Buhr, \& Ladouceur, 2004). The reason for this tendency is man's inner drive to be aware of the future and to be sure of his future experiences (Grenier, Barette, \& Ladouceur, 2005). Dugas et al. (2005) pointed out that individuals who are highly intolerant of uncertainty in the face of an uncertain event interpret the event as annoying and unacceptable, while those who are moderately intolerant of uncertainty regard the event as less annoying. In this regard, it can be said that the intolerance of uncertainty is an individual's interpretation of an event based on his/her feelings and thoughts. Considering the rapidly changing conditions of the $21^{\text {st }}$ century, the idea that a state of uncertainty about the future gains of an individual will affect his/her academic performance and accordingly academic self-efficacy is one of the ideas aimed to be confirmed by the current study.

Another variable thought to be connected with self-efficacy and to affect individuals' academic self-efficacy levels is beliefs about worry. When the literature was examined, it was seen that negative beliefs about anxiety had negative effects on the self-efficacy of individuals about their activities (Sklett, Lorås, \& Sigmundsson, 2018; Yao et al., 2018). In this context, it is considered that individuals' positive or negative anxiety about their academic activities will have an impact on their academic self-efficacy. Worry is defined as an annoying and disturbing feeling aroused by the fear of being harmed or being unlucky or the possibility of being harmed and closely connected with stress (Budak, 2003). When the relevant literature is examined, it is seen that beliefs about worry are associated with generalized anxiety disorder. According to the metacognitive model of generalized anxiety disorder, people may develop both positive and negative beliefs about the impact of their anxiety on themselves (Cartwright-Hatton \& Wells, 1997). The individual's regarding worry as a method of coping with stress-inducing events, as a means of preventing destructive incidences from happening, enabling him/her to take precautions against any unwanted possibility and preventing him/her from seeing the incidences from an emotional perspective are considered to be positive beliefs about worry. The beliefs such as worry will create a destructive feeling in the individual and it will negatively affect the individual's capacity to solve problems and his/her efficiency are negative feelings about worry (Sari \& Dag, 2009). Scientific determination of the relationship between the concepts of academic self-efficacy and positive beliefs about worry will provide important insights into the understanding of how university students' academic self-efficacy can be nurtured.

Another variable that is thought to be related to the concept of academic self-efficacy is the academic locus of control. Academic locus of control is an important determinant of students' academic performance and self-efficacy regarding academic performance (Drago, Rheinheimer, \& Detweiler, 2018). The term locus of control was first mentioned in the social learning theory of Rotter (1954). Rotter (1966) explains the concept of locus of control as a tendency to base positive or negative situations that a person plans to live now or in the future on internal and external causes. In this regard, it can be said that locus of control is an important and determining 
part of the individual's thought system. Locus of control and academic locus of control have similar structures. Academic locus of control is defined as a concept indicating a distribution on a continuum ranging from internal locus of control to external locus of control depending on the extent to which the individual feels responsible and competent in relation to academic works such as doing assignments, preparing for an exam and presenting a project (Saricam \& Duran, 2012). While individuals adopt internal locus of control more as a result of successful experiences, they prefer external locus of control more after experiencing failures. Individuals' academic locus of control is influential on their perceptions of success and failure; at the same time, the successes and failures of individuals have an impact on their academic locus of control. As a result, it can be said that there is a reciprocal determining relationship between academic locus of control and success and failure perception.

\subsection{Importance of Research}

Though in the literature there are studies separately exploring the subjects such as academic self-efficacy, intolerance of uncertainty, positive beliefs about worry and academic locus of control, no study investigating all these concepts together considerably affecting university students' academic achievement has been found in the literature review. When the literature is examined, it appears clear that the concepts of uncertainty (Stanley-Budner, 1962), worry (Borkovec, Stevens, \& Diaz, 1999) and locus of control (Rother, 1966) have significant effects on individuals. Thus, the strongest determinant of university students' achievement, academic self-efficacy is thought to be affected by all these concepts.

Scientific determination of the effect of university students' levels of intolerance of uncertainty, positive beliefs about worry and academic locus of control on their academic self-efficacy can offer important insights for the prediction of whether these students feel academically competent or not. A significant correlation to be found between the concepts can offer important clues about how to nurture students' self-efficacy. Seen from this perspective, it can be argued that academicians can capitalize on the relationships between these concepts while making up the content of psycho-education programs aiming to enhance students' academic self-efficacy. University students can make use of the results of such studies while seeking for the ways of improving their academic achievement and reasons behind their failures. Moreover, the current study can contribute to the identification of the components explaining the concept of academic self-efficacy in the Turkish culture, allowing the comparison of these components with the components explaining the concept of self-efficacy in other cultures.

When the literature is examined, it is seen that academic self-efficacy has not been investigated along with these variables; thus, the current study will the first in this regard. A correlation that can be found between academic self-efficacy and intolerance of uncertainty, positive beliefs about worry and academic locus of control will make an important contribution to the understanding of the complex structure of the concept of academic self-efficacy. Moreover, the current study will make contributions to the body of disciplinary knowledge in the related literature, fill in the gap in the literature and will serve as a source for future studies.

Researchers working in the field of education often try to explain the potential variables that can affect academic self-efficacy by concentrating on the subject of academic self-efficacy. The research has revealed that there is a consistent and positive correlation between academic self-efficacy and many variables affecting students' academic achievement (Atoum \& Al-Momani, 2018; Bahar, 2019; Camelo-Lavadores, Sánchez-Escobedo, \& Pinto-Sosa, 2017; Dadandi, 2018; Doménech-Betoret, Abellán-Roselló, \& Gómez-Artiga, 2017; Koca \& Dadandi, 2019). Though there are studies separately investigating the concepts of academic self-efficacy (Aslan \& Agiroglu-Bakir, 2017; Cava-Kuru, 2018; Grøtan, Sund, \& Bjerkeset, 2019; Korucu \& Cinar, 2017; Makhabbat, Coklar, \& Gunduz, 2018; Qamar, Parveen, \& Yousuf, 2017; Sachitra \& Bandara, 2017; Sokmen, 2018; Sula-Atas \& Kumcagiz, 2019; Verešová \& Foglová, 2017; Ye, Posada, \& Liu, 2018), intolerance of uncertainty (Buhr \& Dugas, 2002; Coskun, 2017; Freeston, Rhéaume, Letarte, Dugas, \& Ladouceur, 1994; Ranney, Behar, \& Bartoszek, 2019; Stanley-Budner, 1962; Sirin-Ayva, 2018; Yildiz, 2017), positive beliefs about worry (Borkovec et al., 1999; Gosselin et al., 2003; Goc, 2017; Karatas \& Uzun, 2018; Penney, Mazmanian, \& Rudanycz, 2013; Thielsch, Andor, \& Ehring, 2018) and academic locus of control (Akin, 2007; Certel \& Kozak, 2017; Celik \& Saricam, 2018; Cok, 2018; Daum \& Wiebe, 2003; Saricam \& Duran, 2012), there is no study focusing on the relationship between academic self-efficacy and intolerance of uncertainty and positive beliefs about worry. However, there are some studies exploring the relationship between academic self-efficacy and academic locus of control (Bong, 1995; Drago et al., 2018; Graham, 2007; Jonson-Reid, Davis, Saunders, Williams, \& Williams, 2005; Kirmizi \& Saricoban, 2018; Kucuk-Kilic, Akbulut, \& Oncu, 2017; Satici, 2013). In this respect, it becomes clear that it is necessary to investigate the potential variables that can affect students' academic self-efficacy, which has been proved to be strongly associated with their academic performance. To this end, the current study aimed to explore the relationship between academic self-efficacy and intolerance of uncertainty, positive beliefs about worry and academic locus of control. 


\subsection{Purpose of the Research}

The purpose of the study was set to be to determine the extent to which intolerance of uncertainty, positive beliefs about worry and academic locus of control predict university students' academic self-efficacy.

\subsection{Research Questions}

The present study seeks to answer the following questions:

a) Is there a meaningful relationship between university students' academic self-efficacy, intolerance to uncertainty, positive beliefs about anxiety, and academic control focuses?

b) Are university students' intolerance to uncertainty, positive beliefs about concern, and academic control focuses a significant predictor of academic self-efficacy?

\section{Method}

\subsection{Research Design}

The current study employed the relational survey model to determine the relationship between university students' academic self-efficacy and intolerance of uncertainty, positive beliefs about worry and academic locus of control and the extent to which these variables predict academic self-efficacy. The relational survey model is a research model aiming to determine the covariance between two or more variables and if there is, the degree of this covariance (Karasar, 2005).

\subsection{Study Group}

The population of the current study is comprised of 14,493 students attending Burdur Mehmet Akif Ersoy University in 2015-2016 academic years. While constructing the sampling, firstly faculties and departments were determined on the basis the random sampling method; then, by using the stratified sampling method, the students were divided into strata on the basis of their grade level and then from these strata, the participants were randomly assigned to the sample group. As a result, a total of 717 students were included in the study on a volunteer basis. The demographic features of the participants are given in Table 1 .

Table 1. Descriptive statistical findings related to the sampling

\begin{tabular}{|c|c|c|c|}
\hline Factor & Variables & $\mathrm{n}$ & $\%$ \\
\hline \multirow{2}{*}{ Gender } & Female & 499 & 69.60 \\
\hline & Male & 218 & 30.40 \\
\hline \multirow{3}{*}{ Age } & $17-19$ & 331 & 46.20 \\
\hline & $20-22$ & 333 & 46.40 \\
\hline & $23-25$ & 53 & 7.40 \\
\hline \multirow{12}{*}{ Department } & Guidance and Psychological Counseling & 79 & 11.00 \\
\hline & Classroom Teaching & 89 & 12.40 \\
\hline & English Teaching & 139 & 19.40 \\
\hline & Turkish Teaching & 43 & 6.00 \\
\hline & Elementary Level Math Teaching & 47 & 6.60 \\
\hline & Emergency Aid and Disaster Management & 61 & 8.50 \\
\hline & Pre-school Teaching & 56 & 7.80 \\
\hline & Science Teaching & 23 & 3.20 \\
\hline & Computer Teaching & 33 & 4.60 \\
\hline & Nursing & 40 & 5.60 \\
\hline & Call Center Services & 52 & 7.30 \\
\hline & Veterinary Faculty & 55 & 7.70 \\
\hline \multicolumn{2}{|c|}{ Total Number of Students } & 717 & 100.00 \\
\hline
\end{tabular}

\subsection{Data Collection Tool and Procedure}

As the data collection instruments, the information form aiming to collect demographic data of the students, the Academic Self-efficacy Scale, the Intolerance of Uncertainty Scale, the Positive Beliefs about Worry Scale, the Academic Locus of Control Scale were used in the current study. After the validity and reliability studies of the instruments to be used to collect data, the final form to be applied to the students was prepared. In order to conduct 
the study, ethical approval was obtained from Burdur Mehmet Akif University and scale application permissions were obtained from related faculties. The scales were applied by the researchers in the classrooms of the students with face to face group application. The students were informed about the study and the scales and after their verbal consents were gained, the scales were administered to the students and completed by them. The administration process lasted 20 minutes on average. The completed scales were examined and the scales not having been completely filled by the students were excluded from the study.

\subsubsection{The Personal Information Form}

A personal information form was developed by the researcher to collect data about the participants' demographic features. The personal information form is intended to collect personal information of the participants (gender, age, department, grade level).

\subsubsection{The Academic Self-Efficacy Scale}

The scale developed by Jerusalem and Schwarzer (1981) was adapted to the Turkish culture by Yilmaz, Gürcay, and Ekici (2007). This four-point Likert scale consisting of 7 items does not have any sub-dimensions. The scale explains $45 \%$ of the total variance. The general internal consistency coefficient of the academic self-efficacy scale is .79. In the current study, the general internal consistency of the scale was found to be .77 .

Sample scale items are presented below:

- When I have prepared enough, I always get high success in the exams.

- I have a comfortable attitude in exam settings because I trust my intelligence.

\subsubsection{The Intolerance of Uncertainty Scale}

The scale developed by Freeston et al. (1994) was adapted to the Turkish culture by Sari and Dag (2009). This is a five-point Likert scale comprised of 26 items. The scale has four sub-dimensions and a total score can be taken from the scale. These four sub-dimensions are uncertainty is stress inducing and depressing; negative self-evaluations related to uncertainty, not knowing what future will bring is annoying and uncertainty prevents me from getting into action and they together explain $49 \%$ of the total variance. The internal consistency coefficients of the sub-dimensions are $.88 ; .79 ; .79 ; .79$, respectively. For the total score of the scale, test-retest correlation was found to be .66 and the general internal consistency was found to be .93 . In the current study, the general internal consistency is .93.

Sample scale items are presented below:

- Uncertainty prevents me from having a solid idea.

- Uncertainty makes me uncomfortable, anxious or stressful.

\subsubsection{The Positive Beliefs about Worry Scale}

The adaptation of the scale developed by Freeston et al. (1994) into the Turkish culture was performed by Sari and Dag (2009). This five-point Likert scale is comprised of 25 items. The scale has three sub-dimensions and a total score is taken from the scale. These three sub-dimensions are worry helps me solve problems and is a source of motivation, worry prevents dangerous and negative results, worry protects against negative feelings and they together explain $57 \%$ of the total variance. The internal consistency coefficients of the sub-dimensions are $.94 ; .82 ; .82$, respectively. For the total score of the scale, test-retest correlation is .74 and the general internal consistency is .95. In the current study, the general internal consistency was found to be .94 .

Sample scale items are presented below:

- Worrying helps me plan my steps to solve a problem.

- Worrying encourages me to act.

\subsubsection{The Academic Locus of Control Scale}

The scale developed by Akin (2007) is a five-point Likert scale consisting of 17 items. The scale has two sub-dimensions and a total score is taken separately for each sub-dimension. These two sub-dimensions are internal locus of control and external locus of control and they together explain $71.7 \%$ of the total variance. The internal consistency coefficients of the sub-dimensions are .94 and .95 , respectively. Test-retest correlation was found to be .97 for the first sub-dimension and .93 for the second sub-dimension. In the current study, the internal consistency coefficients of the sub-dimensions were found to be .81 and .78 , respectively.

Sample scale items are presented below: 
- I think the failures I have experienced are due to my own mistakes.

- I can be successful in classes if I get along well with my teacher.

\subsection{Data Analysis}

First, it was tested whether the data satisfy the parametric requirements needed for regression analysis. For this purpose, Kurtosis and skewness coefficients were examined to determine whether the data satisfy the normal distribution assumption. For all the data, Kurtosis and skewness coefficients range between -1.0 and +1.0 . Kolmogorov Smirnov normality test revealed that the data is normally distributed. For the investigation of outliers in the data set, Mahalonobis distance coefficients and $\mathrm{z}$ score analyses were conducted and no value at the extreme was found. Moreover, in order to satisfy the regression assumption, there mustn't be a relationship between the error terms in the model (Kalayci, 2006). In this line, when the Durbin Watson value used to detect the autocorrelation in the model was examined, it was found that the value desired to be between 1.50 and 2.50 (Kalayci, 2006) is 1.86, there is no autocorrelation in the model, standard errors of the b coefficients are very small and the regression assumption is satisfied. As a result of the statistics conducted, it was decided that the terms are not connected. In the analysis of the data, Pearson product-moment correlation coefficient was used to determine the correlation between the variables and to determine the extent to which these variables predict academic self-efficacy, the hierarchical multiple-regression analysis was used. The hierarchical multiple-regression analysis is an analysis to determine the relationship between a dependent variable and a set of predictive variables. The investigator may introduce the variables into the regression analysis at the desired or specified time. In this study, a stepwise method is used. In this method, after the initial model is created, the most contributing variable model is included in the model and the model contribution of the other variables is tested. Variables that do not contribute to the model are not modeled. In the statistical analyses, SPSS 15.0 program package was used and the significance level was set to be .05 .

\section{Results}

The answer to the first question of the research: Is there a meaningful relationship between university students' academic self-efficacy, intolerance to uncertainty, positive beliefs about anxiety, and academic control focuses?

The collected data were subjected to the hierarchical multiple-regression analysis in order to determine the extent to which intolerance of uncertainty, positive beliefs about worry and academic locus of control predict academic self-efficacy. Before the regression analysis, co-correlation coefficients between the dependent and independent variables were calculated to investigate whether there is a multi-correlation between the dependent and independent variables and the results are presented in Table 2.

Table 2. Between-variables pearson product-moment correlation coefficients

\begin{tabular}{llllll}
\hline Variables & 1 & 2 & 3 & 4 & 5 \\
\hline 1- Academic Self-Efficacy & - & & & & \\
2- Intolerance of Uncertainty & $-.134^{* *}$ & - & & \\
3- Positive Beliefs about Worry & $.121^{* *}$ & $.343^{* *}$ & - & & \\
4- Academic Internal Locus of Control & $.165^{* *}$ & $.135^{* *}$ & .057 & - & \\
5- Academic External Locus of Control & $-.227^{* *}$ & $.314^{* *}$ & $.301^{* *}$ & $-.232^{* *}$ & - \\
\hline
\end{tabular}

$* * \mathrm{p}<.01$.

As can be seen in Table 2, there is a positive correlation between the students' academic self-efficacy levels and positive beliefs about worry $(\mathrm{r}=.121, \mathrm{p}<.01)$ and academic internal locus of control $(\mathrm{r}=.165, \mathrm{p}<.01)$ and a negative and significant correlation with intolerance of uncertainty $(\mathrm{r}=.-134, \mathrm{p}<.01)$ and academic external locus of control $(\mathrm{r}=.-227, \mathrm{p}<.01)$. It is understood from the analyses conducted for the regression assumption and given in the data analysis section and the Durbin Watson value given in that section that these correlations are not such that they can create a multiple-regression problem (lower than .70), that the correlations are at the medium level.

The answer to the second question of the research: Are university students' intolerance to uncertainty, positive beliefs about concern, and academic control focuses a significant predictor of academic self-efficacy?

The results obtained from the Hierarchical Multiple Regression Analysis conducted to determine whether these variables significantly predict academic self-efficacy are given in Table 3. 
Table 3. The results of hierarchical multiple regression analysis related to intolerance of uncertainty, positive beliefs about worry and academic locus of control as the predictors of academic locus of control

\begin{tabular}{|c|c|c|c|c|c|c|c|c|c|c|}
\hline Model & Predictors & $\mathrm{B}$ & SHB & $\beta$ & $\mathrm{t}$ & $\mathrm{p}$ & $\Delta \mathrm{R}^{2}$ & $\mathrm{R}^{2}$ & $\mathrm{~F}$ & $\mathrm{p}$ \\
\hline $1^{\text {st }}$ Model & Intolerance of Uncertainty & -.025 & .007 & -.134 & -3.606 & .00 & .018 & .018 & $13.001 * *$ & .00 \\
\hline \multirow{2}{*}{$2^{\text {nd }}$ Model } & Intolerance of Uncertainty & -.037 & .007 & -.198 & -5.106 & .00 & \multirow{2}{*}{.031} & \multirow{2}{*}{.049} & \multirow{2}{*}{$23.577^{* *}$} & \multirow{2}{*}{.00} \\
\hline & Positive Beliefs about Worry & .031 & .006 & .189 & 4.856 & .00 & & & & \\
\hline \multirow{3}{*}{$3^{\text {rd }}$ Model } & Intolerance of Uncertainty & -.041 & .007 & -.222 & -5.781 & .00 & \multirow{3}{*}{.034} & \multirow{3}{*}{.083} & \multirow{3}{*}{$26.005^{* *}$} & \multirow{3}{*}{.00} \\
\hline & Positive Beliefs about Worry & .03 & .006 & .186 & 4.88 & .00 & & & & \\
\hline & $\begin{array}{c}\text { Academic Internal Locus of } \\
\text { Control }\end{array}$ & .153 & .03 & .185 & 5.10 & .00 & & & & \\
\hline \multirow{4}{*}{$4^{\text {th }}$ Model } & Intolerance of Uncertainty & -.03 & .007 & -.162 & -4.125 & .00 & \multirow{4}{*}{.037} & \multirow{4}{*}{.12} & \multirow{4}{*}{$30.167 * *$} & \multirow{4}{*}{.00} \\
\hline & Positive Beliefs about Worry & .038 & .006 & .235 & 6.106 & .00 & & & & \\
\hline & $\begin{array}{c}\text { Academic Internal Locus of } \\
\text { Control }\end{array}$ & .102 & .031 & .123 & 3.303 & .00 & & & & \\
\hline & $\begin{array}{c}\text { Academic External Locus of } \\
\text { Control }\end{array}$ & -.098 & .018 & -.219 & -5.492 & .00 & & & & \\
\hline
\end{tabular}

$* * \mathrm{p}<.01$

According to the results of the hierarchical multiple regression analysis seen in Table 3, the model constructed to test whether intolerance of uncertainty, positive beliefs about worry and academic locus of control are significant predictors of academic self-efficacy was found to be significant $\left(\mathrm{F}_{(4,712)}=30.167, \mathrm{p}<.01\right)$. These independent variables together explain the students' self-efficacy with $12 \%$ explanation variance. When the t-test results related to the significance of regression coefficients were examined, it was found that positive beliefs about worry $(\beta=.189, \mathrm{t}=4.856, \mathrm{p}<.01)$ and academic internal locus of control $(\beta=.123, \mathrm{t}=5.10, \mathrm{p}<.01)$ variables are significant predictors of academic self-efficacy in a positive direction and intolerance of uncertainty $(\beta=-.134, t=-3.606$, $\mathrm{p}<.01)$ and academic external locus of control $(\beta=-.219, \mathrm{t}=-5.492, \mathrm{p}<.01)$ are significant predictors of academic self-efficacy in a negative direction. When the variables' ratios of explaining academic self-efficacy were examined, it was found that intolerance of uncertainty entered in the first step explains $1.8 \%$ of the variance; intolerance of uncertainty and positive beliefs about worry entered together in the second step explain $4.9 \%$ of the variance; intolerance of ambiguity, positive beliefs about worry and academic internal locus of control entered together in the third step explain $8.3 \%$ of the variance and intolerance of ambiguity, positive beliefs about worry, academic internal locus of control and academic external locus of control entered together in the fourth step explain $12 \%$ of the variance. When the variables' ratios of explaining academic self-efficacy are examined, it is seen that the highest ratio is $3.7 \%$ for all the variables each in the fourth step.

\section{Discussion}

It was concluded that academic self-efficacy is positively and significantly predicted by positive beliefs about worry and academic internal control and negatively and significantly by intolerance of uncertainty and academic external control. It has been consistently pointed out in the literature that academic locus of control is associated with academic self-efficacy (Bong, 1995; Certel \& Kozak, 2017; Drago et al., 2018; Graham, 2007; Jonson-Reid et al., 2005; Kirmizi \& Saricoban, 2018; Kucuk-Kilic et al., 2017; Satici, 2013); yet, there is no other study claiming that positive beliefs about worry and intolerance of uncertainty are connected with academic self-efficacy.

It is observed that university students exhibit intolerance in the face of various situations they experience and thus their academic self-efficacy is negatively affected. Without a doubt, there is a need for a certain sense of predictability, balance and having the control of situations in order to be able to successfully deal with difficulties in every area of life. The individual needs to know what the situation is, what to do in this situation, and what possible outcomes are waiting for him/her. The uncertainty that arises when control and predictability are lost will harm the individual's self-efficacy in every field, as well as his/her academic self-efficacy that significantly affects academic achievement. The closest studies on this subject: The finding of Fetherston et al. (2018) study on college students, indicating that students' ability to manage uncertainty have an effect on self-efficacy of career preparation; the finding of Kim, Rhee, Ha, Yang, and Lee (2016) research on college graduates, indicating that tolerance to uncertainty had a positive effect on the career decision self-efficacy; the finding of Schmitt, Rosing, Zhang, and Leatherbee (2018) research on the world of work, showing that uncertainty situations have negative effects on entrepreneurs with low self-efficacy perception, entrepreneurs with high self-efficacy perception can better cope with uncertain situations; support the finding of the current study that intolerance of uncertainty will 
negative affect academic self-efficacy.

Another variable that predicts university students' academic self-efficacy has been found to be positive beliefs about worry. In the face of an anxiety-inducing situation, if university students regard anxiety as something that can be capitalized on by them rather than as something that can harm them, then their academic self-efficacy is positively affected. In the literature, no study has been found reporting that positive beliefs about worry can contribute to the level of self-efficacy. The closest study to this issue was conducted by Karatas and Uzun (2016) reporting that positive evaluations concerning worry are in a positive correlation with general self-efficacy. In addition, there is some research reporting that negative opinions about worry adversely affect self-efficacy and academic self-efficacy. The finding of Torres and Solberg (2001) indicating that academic self-efficacy is negatively correlated with worry, stress and anxiety etc.; the finding of Sklett et al. (2018) research on athletes, showing that anxiety has a negative impact on the emotional state of athletes, therefore, athletes' anxiety levels and self-efficacy were negatively correlated; the finding of Yao et al. (2018) research on nurses, indicating that stress has a negative impact on the general self-efficacy of nurses; the finding of Pajares (2002) showing that emotional expressions such as worry, stress, and fear lead to the formation of lower level of self-efficacy perception and the finding by Oguz (2012) indicating that emotional variables such as worry, stress, and anxiety negatively affect university students' self-efficacy perceptions accordingly their academic achievement support the finding of the current study that positive beliefs about worry will positively affect academic self-efficacy.

Another variable predicting academic self-efficacy has been found to be academic locus of control. It was found them when university students accomplish their academic tasks as a result of the confidence they feel for their abilities; that is, when they see internal factors as the reason for their academic achievements, their academic self-efficacy is positively affected. On the other hand, it has been found that when external factors such as chance or the difficulty of the course are seen as the reason for being successful in the accomplishment of academic tasks, academic self-efficacy is negatively affected. This finding of the current study concurs with the finding of Satici (2013) showing that with increasing level of academic internal locus of control, individuals' academic self-efficacy also increases; yet, with increasing level of external locus of control, individuals' academic self-efficacy decreases. Bong (1995) states that when students see external factors as the reason for their academic achievements and failures, their academic self-efficacy can decrease; yet, when they see internal factors as the reason, their academic self-efficacy can increase. In their study, Certel and Kozak (2017) found significant relationships between internal and external academic locus of control and academic self-efficacy; they also found that students with higher academic self-efficacy and internal academic locus of control scores had higher academic achievement. Drago et al. (2018) in their study on university students, found that academic locus of control and academic self-efficacy together had a positive and significant effect on students' academic performance. Moreover, according to Graham (2007), academic self-efficacy has a positive and significant correlation with internal locus of control. In addition to this, Jonson-Reid et al. (2005), as a result of their research, found that internal locus of control and external locus of control predict academic self-efficacy. These findings reported in the literature support the finding of the current study indicating that academic self-efficacy is significantly and positively predicted by academic internal locus of control; yet, significantly but negatively predicted by academic external locus of control.

\subsection{The Limits of the Study}

The current study is limited to the opinions of 717 students attending Burdur Mehmet Akif Ersoy University located within the borders of the city of Burdur in the 2015-2016 academic year and the personal information form developed to elicit the demographics of the participants, the academic self-efficacy scale, the intolerance of uncertainty scale, the positive beliefs about worry scale and the academic locus of control scale. Furthermore, as the study was conducted on a volunteer basis, another limitation of the study can be inadequate representation of the departments and faculties involved in the study.

\subsection{Contributions of Research Results, and Recommendations}

It was also concluded that the students' self-efficacy is positively correlated with positive beliefs about worry and academic internal locus of control. The students' academic self-efficacy is nurtured by their positive beliefs about worry and academic internal locus of control; thus, these variables need to be promoted. The dominance of internal locus of control on the decisions made by students and their making positive evaluations in the face of anxiety-inducing events they experience will positively affect their academic self-efficacy levels and thus contribute to their achievements in many fields of life. Furthermore, eliminating the ambiguities that students have in mind for the present and future will contribute positively to their academic self-efficacy. In this regard, students should be supported by educators, parents and social circles to improve their academic self-efficacy and they should be recognized and rewarded for even minor successes. In light of these findings of the current study, the 
following suggestions can be made:

Similar studies can be planned on the basis of the mixed method by adding quantitative research methods. By constructing experimental studies, it can be evaluated how much academic self-efficacy can be enhanced by designing activities to decrease intolerance of uncertainty and external locus of control and to promote positive beliefs about worry and academic internal locus of control. The main goal of the current study is to determine whether the university students' intolerance of uncertainty, positive beliefs about worry and academic locus of control predict their academic self-efficacy. Further research can focus on different variables (cognitive distortions, the difficulty of the task etc.), which will make contributions to the better understanding of university students' academic self-efficacy. The scales can be administered to larger samplings. The study group of the current research is comprised of students selected from 12 departments of five faculties in a university. Same variables can be tested in individual faculties and departments or in different levels of schooling (elementary, secondary, high school, postgraduate etc.). It was found that strong academic self-efficacy is related to some variables that can positively affect students' school achievement. Therefore, seminars can be organized to show the importance of academic self-efficacy to academicians, teachers and parents and their awareness of academic self-efficacy can be raised. Moreover, psycho-educational programs can be developed to strengthen university students' academic self-efficacy. Such programs can include activities that can decrease intolerance of uncertainty and external locus of control and improve positive beliefs about worry and internal locus of control. Within universities, psychological counseling centers can be opened so that students who feel depressed and anxious against uncertain situations can be taught the nature of uncertainty, uncertainty management and proper responses to uncertainty. Moreover, the components used to explain self-efficacy in the Turkish culture can be compared with the components used to explain self-efficacy in other cultures.

\section{References}

Akin, A. (2007). Akademik kontrol odagi olcegi: Gecerlik ve guvenirlik calismasi. Cukurova Universitesi Egitim Fakultesi Dergisi, 34(3), 9-17.

Aslan, M., \& Agiroglu-Bakir, A. (2017). Evaluation of prospective teachers in terms of academic self-efficacy and professional competence. European Journal of Educational Research, 6(4), 553-563. https://doi.org/10.12973/eu-jer.6.4.553

Atoum, A. Y., \& Al-Momani, A. (2018). Perceived self-efficacy and academic achievement among Jordanian students. Trends in Technical \& Scientific Research, 3(1), 1-6.

Bahar, H. H. (2019). Sinif ogretmen adaylarinda akademik oz-yeterlik algisinin akademik basariyi yordama gucu. Ilkogretim Online, 18(1), 149-157. https://doi.org/10.17051/ilkonline.2019.527178

Bandura, A. (1997). Self-efficacy: The exercise of control. New York: W. H. Freeman and Company.

Bong, M. (1995). Epistemological beliefs and generalizability of self-efficacy: Implications for instructional design (Unpublished Ph.D. thesis). University of Southern California, California.

Borkovec, T. D., Stevens, H. H., \& Diaz, M. L. (1999). The role of positive beliefs about worry in generalized anxiety disorder and its treatment. Clin Psychol Psychother, 6, 126-138. https://doi.org/10.1002/(SICI)1099-0879(199905)6:2<126::AID-CPP193>3.0.CO;2-M

Budak, S. (2003). Psikoloji sozlugu. Ankara: Bilim ve Sanat Yayinlari.

Buhr, K., \& Dugas, M. J. (2002). The intolerance of uncertainly scale: Psychometric properties of the English version. Behaviour Research and Therapy, 40, 931- 945. https://doi.org/10.1016/S0005-7967(01)00092-4

Camelo-Lavadores, A. K., Sánchez-Escobedo, P., \& Pinto-Sosa, J. (2017). Academic self-efficacy of high achieving students in Mexico. Journal of Curriculum and Teaching, 6(2), 84-89. https://doi.org/10.5430/jct.v6n2p84

Cartwright-Hatton, S., \& Wells, A. (1997). Beliefs about worry and intrusions: The meta-cognitions questionnaire and its correlates. Journal of Anxiety Disorders, 11(3), 279-296. https://doi.org/10.1016/S0887-6185(97)00011-X

Cava-Kuru, G. (2018). Sinif ogretmeni adaylarinin akademik oz-yeterliklerinin cesitli degiskenler acisindan incelenmesi (Unpublished master's thesis). Mugla Sitki Kocman University Institute of Educational Sciences, Mugla.

Celik, I., \& Saricam, H. (2018). The relationships between positive thinking skills, academic locus of control and grit in adolescents. Universal Journal of Educational Research, 6(3), 392-398. 
https://doi.org/10.13189/ujer.2018.060305

Certel, Z., \& Kozak, M. (2017). The examination of relationships between academic self-efficacy, academic procrastination, and locus of academic control of athletes in different sports. The Sport Journal, 19, 1-10.

Cok, R. (2018). Universite ogrencilerinde cesitli akademik degiskenlerin siber aylaklik davranislarini yordama durumlarinin incelenmesi (Unpublished master's thesis). Inonu University Institute of Educational Sciences, Malatya.

Coskun, S. (2017). An exploratory study on the relationship between the ambiguity tolerance and participation of English language learners (Unpublished master's thesis). Dokuz Eylul University Institute of Educational Sciences, Izmir.

Dadandi, I. (2018). Genel yetenek, akademik benlik kavrami, akademik oz-yeterlik, benlik saygisi, ogrenci bagliligi ve akademik basari arasindaki iliskiler (Unpublished master's thesis). Karadeniz Teknik University Institute of Educational Sciences, Trabzon.

Daum, T. L., \& Wiebe, G. (2003). Locus of control, personal meaning and self-concept before and after an academic critical incident (Unpublished master's thesis). Trinity Western University, USA.

Doménech-Betoret, F., Abellán-Roselló, L., \& Gómez-Artiga, A. (2017). Self-efficacy, satisfaction, and academic achievement: The mediator role of students' expectancy-value beliefs. Frontiers in psychology, 8 , 1193. https://doi.org/10.3389/fpsyg.2017.01193

Drago, A., Rheinheimer, D. C., \& Detweiler, T. N. (2018). Effects of locus of control, academic self-efficacy, and tutoring on academic performance. Journal of College Student Retention: Research, Theory \& Practice, 19(4), 433-451. https://doi.org/10.1177/1521025116645602

Dugas, M. J., Buhr, K., \& Ladouceur, R. (2004). The role of intolerance of uncertainty in etiology and maintenance. In R. G. Heimberg, C. L. Turk, \& D. S. Mennin (Eds.), Generalized anxiety disorder: Advances in research and practice (pp. 142-163). New York, NY: Guilford Press.

Dugas, M. J., Hedayati, M., Karavidas, A., Buhr, K., Francis, K., \& Phillips, N. A. (2005). Intolerance of uncertainty and information processing: Evidence of biased recall and interpretations. Cognitive Therapy and Research, 29(1), 57-70. https://doi.org/10.1007/s10608-005-1648-9

Eggen, P., \& Kauchak, D. (1999). Educational psychology. New Jersey: Printice-Hall, Inc.

Fetherston, M., Cherney, M. R., \& Bunton, T. E. (2018). Uncertainty, technology use, and career preparation self-efficacy. Western Journal of Communication, 82(3), 276-295. https://doi.org/10.1080/10570314.2017.1294704

Freeston, M. H., Rhéaume, J., Letarte, H., Dugas, M. J., \& Ladouceur, R. (1994). Why do people worry? Personality and Individual Differences, 17(6), 791-802. https://doi.org/10.1016/0191-8869(94)90048-5

Goc, E. (2017). Surekli kayginin yordayicilari olarak belirsizlige tahammulsuzluk, endise ile ilgili inanclar ve kontrol odaginin incelenmesi ile yasam doyumunun arastirilmasi (Unpublished master's thesis). Beykent University Institute of Social Sciences, Istanbul.

Gosselin, P., Ladouceur, R., Langlois, F., Freeston, M. H., Dugas, M. J., \& Bertrand, J. (2003). Development and validation of a new measure of erroneous beliefs about worry. European Review of Applied Psychology, 53, 199-211.

Graham, S. (2007). Learner strategies and self-efficacy: Making the connection. Language Learning Journal, 35(1), 81-93. https://doi.org/10.1080/09571730701315832

Grenier, S., Barrette, A. M., \& Ladouceur, R. (2005). Intolerance of uncertainty and intolerance of ambiguity: Similarities and differences. Personality and Individual Differences, 39(3), 593-600. https://doi.org/10.1016/j.paid.2005.02.014

Grøtan, K., Sund, E. R., \& Bjerkeset, O. (2019). Mental health, academic self-efficacy and study progress among college students-The SHoT study, Norway. Frontiers in Psychology, 10, 45. https://doi.org/10.3389/fpsyg.2019.00045

Jerusalem, M., \& Schwarzer, R. (1981). Fragebogen zur erfassung von selbstwirksamkeit. In R. Schwarzer (Ed.), Skalen zur Befindlichkeit und Persoenlichkeit (Research Report No. 5). Berlin: Freie Universitaet, Institut fuer Psychologie.

Jonson-Reid, M., Davis, L., Saunders, J., Williams, T., \& Williams, J. H. (2005). Academic self-efficacy among 
African American youth: Implications for school social work practice. Children \& Schools, 27(1), 5-14. https://doi.org/10.1093/cs/27.1.5

Kalayci, S. (2006). SPSS uygulamali cok degiskenli istatistik teknikleri. Ankara: Asil Yayin Dagitim.

Karasar, N. (2005). Bilimsel arastirma yontemi. Ankara: Nobel Yayin Dagitim.

Karatas, Z., \& Uzun, K. (2016). Universite ogrencilerinin genel oz-yetkinliginin yordayicisi olarak endisenin sonuclari ve kontrol odagi. In O. Demirel, \& S. Dincer (Eds.), Egitim bilimlerinde yenilikler ve nitelik arayisi (pp. 605-616). Ankara: Pegem A Yayincilik. https://doi.org/10.14527/9786053183563.037

Karatas, Z., \& Uzun, K. (2018). Belirsizlige tahammulsuzlugun yordayicisi olarak endise ile ilgili olumlu ve olumsuz inanclar. Kastamonu Egitim Dergisi, 26(4), 1267-1276. https://doi.org/10.24106/kefdergi.434169

Kim, B., Rhee, E., Ha, G., Yang, J., \& Lee, S. M. (2016). Tolerance of uncertainty: links to happenstance, career decision self-efficacy, and career satisfaction. The Career Development Quarterly, 64(2), 140-152. https://doi.org/10.1002/cdq.12047

Kirmizi, O., \& Saricoban, A. (2018). Prospective EFL teachers' locus of control and academic self-efficacy in Turkish context. Journal of Language and Linguistic Studies, 14(3), 308-324.

Koca, F., \& Dadandi, I. (2019). Akademik oz-yeterlik ile akademik basari arasindaki iliskide sınav kaygisi ve akademik motivasyonun araci rolu. Ilkogretim Online, 18(1), 241-252. https://doi.org/10.17051/ilkonline.2019.527207

Korucu, A. T., \& Cinar, D. (2017). Egitim fakultesi ogrencilerinin akademik oz-yeterlik durumlarinin incelenmesi. YYU Egitim Fakultesi Dergisi, 14(1), 73-101. https://doi.org/10.23891/yyuni.2017.3

Kucuk-Kilic S., Akbulut, V., \& Oncu, E. (2017). Akademik kontrol odagi ve akademik oz-yeterlik: Beden egitimi ve spor yuksekokulu ogrencileri ornegi. In 10. Spor Bilimleri Ogrenci Kongresi 10-12 May 2017 (p. 102). Kirikkale: Kirikkale Universitesi.

Makhabbat, A., Coklar, A. N., \& Gunduz, S. (2018). Egitim arastirmasina yonelik tutum ile akademik gudulenme ve akademik ozyeterlik arasindaki iliski. Ahi Evran Universitesi Kirsehir Egitim Fakultesi Dergisi, 19(1), 786-801. https://doi.org/10.29299/kefad.2018.19.022

Oguz, A. (2012). Sinif ogretmeni adaylarinin akademik oz-yeterlik inanclari. Anadolu Journal of Educational Sciences International, 2(2), 15-28.

Pajares, F. (2002). Overview of social cognitive theory and of self-efficacy. Thought A Review Of Culture And Idea. Retrieved from https://doi.org/http://www.emory.edu/education/mfp/eff.html

Penney, A. M., Mazmanian, D., \& Rudanycz, C. (2013). Comparing positive and negative beliefs about worry in predicting generalized anxiety disorder symptoms. Canadian Journal of Behavioural Science/Revue canadienne des sciences du comportement, 45(1), 34. https://doi.org/ 10.1037/a0027623

Qamar, A., Parveen, Q., \& Yousuf, M. I. (2017). Relationship between parenting styles and academic $\begin{array}{lllll}\text { self-efficacy of } \quad \text { students. The } & \text { Anthropologist, }\end{array}$ https://doi.org/10.1080/09720073.2017.1316611

Ranney, R. M., Behar, E., \& Bartoszek, G. (2019). Individuals intolerant of uncertainty: The maintenance of worry and distress despite reduced uncertainty. Behavior therapy, 50(3), 489-503. https://doi.org/10.1016/j.beth.2018.08.006

Rotter, J. B. (1954). Social Learning and Clinical Psychology. Englewood Cliffs, NJ: Prentice-Hall. https://doi.org/10.1037/10788-000

Rotter, J. B. (1966). Generalized expectancies for internal versus external control of reinforcement. Psychological Monographs, 80(1), 1-28. https://doi.org/10.1037/h0092976

Sachitra, K. M. V., \& Bandara, U. (2017). Measuring the academic self-efficacy of undergraduates: The role of gender and academic year experience. World Academy of Science, Engineering and Technology, 11(11), 2320-2325. https://doi.org/10.5281/zenodo.1132491

Sari, S. (2007). Surekli kayginin yordayicilari olarak belirsizlige tahammulsuzluk, endise ile ilgili inanclar ve kontrol odaginin incelenmesi (Unpublished master's thesis). Hacettepe University Institute of Social Sciences, Ankara.

Sari, S., \& Dag, I. (2009). Belirsizlige tahammulsuzluk olcegi, endise ile ilgili olumlu inanclar olcegi ve endisenin sonuclari olceginin Turkce'ye uyarlanmasi, gecerliligi ve guvenilirligi. Anadolu Psikiyatri Dergisi, 
10, 261-270.

Saricam, H., \& Duran, A. (2012). The investigation of the education faculty students' academic locus of control levels. In 15th Balkan International Conference 28-30 June 2012. Romania: Bucreast.

Satici, S. A. (2013). Universite ogrencilerinin akademik oz-yeterliklerinin cesitli degiskenler acisindan incelenmesi (Unpublished master's thesis). Anadolu University Institute of Educational Sciences, Eskisehir.

Schmitt, A., Rosing, K., Zhang, S. X., \& Leatherbee, M. (2018). A dynamic model of entrepreneurial uncertainty and business opportunity identification: Exploration as a mediator and entrepreneurial self-efficacy as a

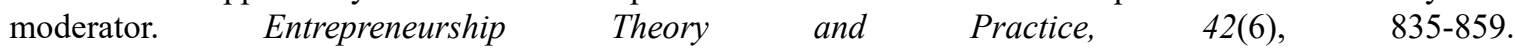
https://doi.org/10.1177/1042258717721482

Sirin-Ayva, A. B. (2018). Macera terapisi temelli grupla danismanligin universite ogrencilerinde bilissel esneklik ve belirsizlige tahammulsuzluge etkisi (Unpublished Ph.D. thesis). Marmara University Institute of Educational Sciences, Istanbul.

Sklett, V. H., Lorås, H., \& Sigmundsson, H. (2018). Self-efficacy, flow, affect, worry and performance in elite world cup ski jumping. Frontiers in Psychology, 9, 1215. https://doi.org/10.3389/fpsyg.2018.01215

Sokmen, A. S. (2018). Uskudar Universitesi ogrencilerinde saldirganlik ve akademik oz-yeterlik arasindaki iliskinin incelenmesi (Unpublished master's thesis). Uskudar University Institute of Social Sciences, Istanbul.

Stanley-Budner, N. Y. (1962). Intolerance of ambiguity as a personality variable. Journal of Personality, 30(1), 29-50. https://doi.org/10.1111/j.1467-6494.1962.tb02303.x

Sula-Atas, N., \& Kumcagiz, H. (2019). Academic procrastination attitudes of adolescents, academic self-efficacy beliefs and perfectionism levels. Hacettepe University Journal of Education. Advance online publication. https://doi.org/10.16986/HUJE.2019050341

Thielsch, C., Andor, T., \& Ehring, T. (2018). Assessing metacognitive beliefs about worry: Validation of German versions of the Why Worry Scale II and the Consequences of Worry Scale. PeerJ, 6, e5177. https://doi.org/10.7717/peerj.5177

Torres, J. B., \& Solberg, V. S. (2001). Role of self-efficacy, stress, social integration, and family support in Latino college student persistence and health. Journal of Vocational Behavior, 59(1), 53-63. https://doi.org/10.1006/jvbe.2000.1785

Verešová, M., \& Foglová, L. (2018). Academic self-efficacy, approach to learning and academic achievement. Health and Academic Achievement, 177-196. https://doi.org/10.5772/intechopen.70948

Wuebbels, A. L. (2006). The development of a social emotional and academic selfefficacy curriculum for sixth grade adolescent students (Unpublished Ph.D. thesis). School of Saint Louis University, Missouri.

Yao, Y., Zhao, S., Gao, X., An, Z., Wang, S., Li, H., ... \& Dong, Z. (2018). General self-efficacy modifies the effect of stress on burnout in nurses with different personality types. BMC health services research, 18(1), 667. https://doi.org/10.1186/s12913-018-3478-y

Ye, L., Posada, A., \& Liu, Y. (2018). The moderating effects of gender on the relationship between academic stress and academic self-efficacy. International Journal of Stress Management, 25(S1), 56. https://doi.org/10.1037/str0000089

Yildiz, B. (2017). Guvenli baglanma stili kazandirma yonelimli psikoegitim programinin belirsizlige tahammulsuzluk ve akademik erteleme uzerindeki etkisi (Unpublished master's thesis). Sakarya University Institute of Educational Sciences, Sakarya.

Yilmaz, M., Gurcay, D., \& Ekici, G. (2007). Akademik oz-yeterlik olceginin Turkce'ye uyarlanmasi. Hacettepe University Egitim Fakultesi Dergisi, 33, 253-259.

Zychowski, L. A. (2007). Academic and social predictors of college adjustment among first-year students: Do high school friendships make a difference? (Unpublished Ph.D. thesis). Indiana University, Pennsylvania.

\section{Note}

This study was produced from the master thesis prepared by the first author under the supervision of the second author' to the article. 


\section{Copyrights}

Copyright for this article is retained by the author(s), with first publication rights granted to the journal.

This is an open-access article distributed under the terms and conditions of the Creative Commons Attribution license (http://creativecommons.org/licenses/by/4.0/). 